\title{
Continuous postoperative infusion of remifentanil inhibits the stress responses to tracheal extubation of patients under general anesthesia
}

This article was published in the following Dove Press journal:

Journal of Pain Research

19 April 2017

Number of times this article has been viewed

\section{Guoliang Zhao \\ Xiaoyue Yin \\ Ya Li \\ Jianlin Shao}

Department of Anesthesiology, The First Affiliated Hospital of Kunming Medical University, Kunming, People's Republic of China
Correspondence: Jianlin Shao Department of Anesthesiology, The First Affiliated Hospital of Kunming Medical University, 295 Xichang Road, Kunming 650032, People's Republic of China Tel +8687I653360I5 Email janelinshaow@I63.com
Purpose: The study aimed to assess the combined effects of parecoxib with three different doses of remifentanil and its effect on the stress and cough responses following tracheal extubation under general anesthesia.

Methods: A total of 120 patients with American Society of Anesthesiologists (ASA) scores of I or II, undergoing selective thyroidectomy with total intravenous anesthesia (propofol-remifentanil) and tracheal intubation, were randomly allocated to be treated with an intravenous injection of parecoxib and a continuous infusion of remifentanil at $0.1 \mu \mathrm{g} / \mathrm{kg} / \mathrm{min}$ (R1), $0.2 \mu \mathrm{g} / \mathrm{kg} / \mathrm{min}$ (R2), $0.3 \mu \mathrm{g} / \mathrm{kg} / \mathrm{min}$ (R3), or an isotonic saline injection (the control group). Hemodynamic vital signs, emergence time, extubation time, sedation-agitation scale (SAS) score, pain visual analog scale (VAS) score, occurrence of coughing, and side effects were recorded before surgery and during the peri-extubation period. The vital signs included blood pressure (BP), heart rate $(\mathrm{HR})$, respiratory rate $(\mathrm{R})$, and peripheral arterial oxygen saturation $\left(\mathrm{SPO}_{2}\right)$.

Results: BP, HR, the occurrence rate of coughing, and extubation awareness decreased with the dose of remifentanil, and the differences among the groups were significant $(P<0.05)$. Emergence and extubation time increased with the dose of remifentanil, and the differences among the groups were significant $(P<0.05)$. The occurrence rates of respiratory depression and bradycardia in group R3 were significantly higher than those in other groups $(P<0.05)$. SAS and VAS were lowest in group R3, and the differences among the groups were significant $(P<0.05)$. BP, HR, SAS, and VAS increased with time in the remifentanil groups.

Conclusion: The combined use of parecoxib and a moderate dose of remifentanil can effectively suppress the stress and coughing responses during the peri-extubation period. The appropriate quantity of remifentanil was found to be $0.2 \mu \mathrm{g} / \mathrm{kg} / \mathrm{min}$, as this dosage caused no side effects. Keywords: remifentanil, continuous infusion, stress response, coughing, tracheal extubation, anesthesia

\section{Introduction}

Tracheal extubation is commonly performed during the emergence phase after stopping anesthetics. Significant systemic stress responses to pain and airway stimulation can occur during this period, including agitation and cough, which may cause hypertension, tachycardia, and increased intracranial hypertension. ${ }^{1}$ This not only greatly increases the discomfort of patients but it also increases the rates of angiocardiopathy and other side effects. Gacouin et $\mathrm{al}^{2}$ evaluated 203 patients' pain using a visual analog scale (VAS), and they found $>73 \%$ of patients experienced moderate or severe pain during extubation. Traditionally, anesthetic withdrawal involves discontinuing both propofol and remifentanil, which can result in pain experienced by patients in an unawakened state and which can lead to a stress response induced by the tracheal catheter. This 
widely increases the probability of dysphoria and adverse reactions during the peri-extubation period. Therefore, it is extremely important to identify a method to effectively reduce the stress response during peri-extubation.

Remifentanil is a new ultra-short-acting opioid $\mu$-receptor stimulant, with rapid onset and offset activity, which can also be rapidly hydrolyzed in tissue and blood with no dependence on liver and kidney function. ${ }^{3}$ Continuous infusion of remifentanil has no prolonged context-sensitive half-time or cumulative effects, ${ }^{4}$ which makes it easier to maintain a stable concentration at the effect site. Therefore, remifentanil is widely used for clinical anesthesia. ${ }^{5}$ Remifentanil not only has an anesthetic and analgesic effect but it can also reduce the incidence of respiratory depression and other adverse reactions. The use of a continuous infusion of remifentanil after total intravenous anesthesia has multiple advantages, as remifentanil can be used to control excessive stress responses. ${ }^{6}$ Aouad et $\mathrm{al}^{7}$ showed that the use of a small dose of remifentanil did not prolong the time taken to wake up from anesthesia, and it decreased the occurrence of cough during the emergence phase.

As a previous study showed, the use of remifentanil often results in postoperative discomfort and hyperalgesia. ${ }^{8}$ Therefore, a long-acting postoperative analgesic is of urgent need to avoid postoperative hyperalgesia and pain caused by remifentanil. Parecoxib is a new nonsteroidal anti-inflammatory drug (NSAID) that has selective cyclooxygenase-2 inhibitory activity, strong anti-inflammatory analgesic activity, long-term efficacy, ${ }^{8}$ and minimal cardiovascular risk. ${ }^{9}$ Many studies have shown that NSAIDs can ameliorate the side effects caused by opioids, including respiratory depression, nausea, emesis, and somnolence, ${ }^{10}$ so parecoxib is often used as a postoperative analgesic.

Until now, the appropriate dose of remifentanil for inhibiting stress responses has remained unclear. The stress response that occurs during major surgeries is not only related to the irritation caused by the endotracheal tube but also to the surgical stimulation of patients during the emergence phase. Therefore, this study aimed to explore the combined effect of parecoxib with different doses of remifentanil on hemodynamic vital signs and stress responses to extubation.

\section{Patients and methods}

\section{Patients}

We obtained approval from the institutional review board of the First Affiliated Hospital of Kunming Medical University, People's Republic of China, and written informed consent from the patients. A total of 120 patients with American Society of Anesthesiologists scores of I or II, who were
20-50 years old and weighed $40-75 \mathrm{~kg}$, were selected to take part in the study, which involved elective thyroidectomy with general anesthesia and tracheal intubation. Patients with the following characteristics were excluded from the study: patients with an allergy to opioids or NSAIDs, hypertension, a history of ischemic heart disease, or a history of cerebrovascular disease. The included patients were randomly divided into four groups with 30 patients per group: control group, low-dose remifentanil group (R1), medium-dose remifentanil group (R2), and high-dose remifentanil group (R3).

\section{Procedure}

After entering the operating room, the blood pressure (BP), heart rate $(\mathrm{HR})$, respiratory rate $(\mathrm{R})$, and peripheral arterial oxygen saturation $\left(\mathrm{SPO}_{2}\right)$ of each patient were routinely monitored. The venous channel was opened and an isotonic saline solution $(10 \mathrm{ml} / \mathrm{kg} / \mathrm{h})$ was administered. After the patient reached a stable condition, anesthesia induction was performed. For the patients in all four groups, this involved the intravenous infusion of fentanyl $(4 \mu \mathrm{g} / \mathrm{kg})$, rocuronium bromide $(0.6 \mathrm{mg} / \mathrm{kg})$, and propofol $(2.5 \mathrm{mg} / \mathrm{kg})$.

Then anesthesia was maintained using a venous perfusion of propofol $(6-12 \mathrm{mg} / \mathrm{kg} / \mathrm{h})$ and remifentanil $(0.1-0.5 \mu \mathrm{g} / \mathrm{kg} / \mathrm{min})$ before the incision suture. The doses were changed according to each patient's response. When suturing the incision, the patients in all four groups received an intravenous infusion of parecoxib (40 $\mathrm{mg})$ and an intravenous drip of tropisetron ( $4 \mathrm{mg}$ ). The patients in the control group received an isotonic saline injection (instead of propofol and remifentanil). In contrast, the patients in groups R1, R2, and R3 were treated with intravenous remifentanil at $0.1 \mu \mathrm{g} / \mathrm{kg} / \mathrm{min}, 0.2 \mu \mathrm{g} / \mathrm{kg} / \mathrm{min}$, and $0.3 \mu \mathrm{g} / \mathrm{kg} / \mathrm{min}$, respectively.

After the operation, the patients' responses to commands were monitored every $2 \mathrm{~min}$. Patients who could open their eyes on command and responded to commands were assessed as being conscious. Extubation and discontinuation of remifentanil were initiated when the patients had the following conditions: response to commands, spontaneous respiration, deglutition reflex, tidal volume $>8 \mathrm{ml} / \mathrm{kg}$, respiratory rate $>10$ times $/ \mathrm{min}$, and $\mathrm{SPO}_{2}>95 \%$.

\section{Observation indexes}

The BP, HR, R, and $\mathrm{SPO}_{2}$ of each patient were monitored before anesthesia induction (at baseline), and these indexes were also monitored when the patient was in a waking state, at extubation, and at 2, 5, 10, and 15 min after extubation. The emergence time was defined as the time between discontinuation of propofol and the point at which the patient 
regained consciousness. The extubation time was defined as time between the discontinuation of propofol and extubation. The operation, emergence, and extubation times of each patient were recorded. The times and severity of cough during the extubation time were recorded. Anesthesia-, extubation-, and remifentanil-related adverse reactions were also recorded, which included intraoperative awareness, comfort level during extubation, cough, laryngospasm, encephalalgia, dizziness, nausea, emesis, uroschesis, and skin pruritus. Furthermore, the sedation-agitation scale (SAS; 1 = unarousable;

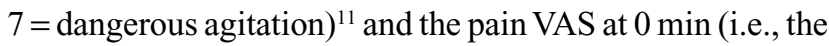
time at which the patient regained consciousness), and 5, 10, and $15 \mathrm{~min}$ after recovery of consciousness, were recorded to evaluate the patients' sedation levels.

\section{Statistical analysis}

Statistical analyses were performed using SPSS 17.0 statistical software (SPSS Inc., Chicago, IL, USA). The qualitative data are presented as frequencies (with percentages), and comparison among the groups was performed using chisquare tests with $\alpha=0.05$. A normality test was carried out for each quantitative variable. The normally distributed data are presented as mean \pm standard deviation, and comparison among the groups was performed using one-way analysis of variance (ANOVA). The non-normally distributed data are presented as medians (with ranges), and comparison among the groups was performed using nonparametric tests. Repeated-measures analyses of the effects of the different treatments and times on the SAS and VAS scores were performed using generalized estimating equations (GEEs). We selected $\alpha=0.05$ as the standard level of significance and so $P<0.05$ was considered statistically significant.

\section{Results}

In this study, 120 patients were selected and there were 30 patients in each group. As shown, gender, age, surgical time, nausea, emesis, dizziness, headache, intraoperative awareness, and uroschesis in the control, R1, R2, and R3 groups were not significantly different (Table 1). The emergence and extubation times were different among the groups, with increases in remifentanil dose, and considerably longer times in group R2 (remifentanil at $0.2 \mu \mathrm{g} / \mathrm{kg} / \mathrm{min}$ ) and group R3 (remifentanil at $0.3 \mu \mathrm{g} / \mathrm{kg} / \mathrm{min}$ ) compared to the time in group R1 (remifentanil at $0.1 \mu \mathrm{g} / \mathrm{kg} / \mathrm{min}$ ) and control group $(P<0.05)$. The number of patients with a cough in each group decreased with remifentanil dose, and the differences were significant (21 in the control group, 18 in group R1, 8 in group R2, and 3 in group R3, $P=0.000$ ). The number of patients with respiratory depression was higher in the group with the highest dose of remifentanil ( 1 in groups $\mathrm{R} 1$ and $\mathrm{R} 2$ and 7 in group R3, $P=0.002$ ). The number of patients in each group unknown about the extubation increased with the remifentanil dose, and all the patients in groups $\mathrm{R} 2$ and R3 knew about extubation (14, 25, 30, and 30 in the control, $\mathrm{R} 1$, R2, and R3 groups, respectively, $P=0.000$ ). Only $10 \%$ of patients in group R3 had bradycardia and $9 \%$ of patients

Table I Comparison of patient characteristics and postoperative complications

\begin{tabular}{|c|c|c|c|c|c|}
\hline Variable & Group C & Group RI & Group R2 & Group R3 & $\mathbf{P}$ \\
\hline Gender, n (\%) & & & & & 0.065 \\
\hline Male & $3(10.0 \%)$ & $10(33.3 \%)$ & II (36.7\%) & $6(20.0 \%)$ & - \\
\hline Female & 27 (90.0\%) & $20(66.7 \%)$ & $19(63.3 \%)$ & $24(80.0 \%)$ & - \\
\hline Age, mean $\pm S D$ & $40.47 \pm 11.65^{\mathrm{a}}$ & $43.6 \pm 12.24^{a}$ & $42.1 \pm 12.44^{\mathrm{a}}$ & $37.53 \pm 11.13^{\mathrm{a}}$ & 0.236 \\
\hline BMI, median (range) & $21.92(17.99,25.97)^{\mathrm{a}}$ & $22.72(16.61,30.45)^{\mathrm{a}}$ & $23.83(17.97,29.76)^{\mathrm{a}}$ & $22.1(17.69,29.52)^{\mathrm{a}}$ & 0.046 \\
\hline Surgical time (min), median (range) & $115(60,215)$ & $107.5(50,240)$ & $122.5(45,315)$ & $125(70,210)$ & 0.264 \\
\hline Emergence time (min), median (range) & $12(6,23)^{\mathrm{a}}$ & $15(6,30)^{\mathrm{a}, \mathrm{c}}$ & $20(14,30)^{\mathrm{b}, \mathrm{c}}$ & $25.5(15,45)^{b}$ & 0.000 \\
\hline Extubation time (min), median (range) & $16(16,16)^{a}$ & $18(8,35)^{\mathrm{a}, \mathrm{c}}$ & $23(9,36)^{b, c}$ & $31.5(17,47)^{b}$ & 0.000 \\
\hline Cough, n (\%) & $21(70.0 \%)^{\mathrm{a}}$ & $18(60.0 \%)^{\mathrm{a}}$ & $8(27.7 \%)^{b}$ & $3(10.0 \%)^{b}$ & 0.000 \\
\hline Respiratory depression, $\mathrm{n}(\%)$ & $0^{\mathrm{a}}$ & I $(3.3 \%)^{a, b}$ & I $(3.3 \%)^{a, b}$ & $7(23.3 \%)^{b}$ & 0.002 \\
\hline Bradycardia, n (\%) & $0^{\mathrm{a}}$ & $0^{\mathrm{a}}$ & $0^{\mathrm{a}}$ & $3(10.0 \%)^{\mathrm{a}}$ & 0.027 \\
\hline Muscle rigidity, $\mathrm{n}(\%)$ & 0 & 0 & 0 & 0 & - \\
\hline Nausea and emesis, $n(\%)$ & 14 (48.3\%) & $8(27.7 \%)$ & II (36.7\%) & $10(33.3 \%)$ & 0.144 \\
\hline Dizziness headache, $\mathrm{n}(\%)$ & $10(33.3 \%)$ & II (36.7\%) & $9(30.0 \%)$ & $6(20.7 \%)$ & 0.244 \\
\hline Intraoperative awareness, $\mathrm{n}(\%)$ & $\mathrm{I}(3.3 \%)$ & I (3.3\%) & $2(6.9 \%)$ & 0 & 0.659 \\
\hline Uroschesis, n (\%) & $4(13.3 \%)$ & $5(16.7 \%)$ & $2(6.7 \%)$ & I (3.3\%) & 0.104 \\
\hline Unknown about extubation, n (\%) & $14(46.7 \%)^{\mathrm{a}}$ & $25(83.3 \%)^{b}$ & $30(100 \%)^{b}$ & $30(100 \%)^{b}$ & 0.000 \\
\hline Awareness with comfort, $\mathrm{n}(\%)$ & $4(13.3 \%)^{a}$ & $3(10.0 \%)^{\mathrm{a}}$ & $0^{\mathrm{a}}$ & $0^{\mathrm{a}}$ & 0.009 \\
\hline Tolerable discomfort, $\mathrm{n}(\%)$ & $4(13.3 \%)^{\mathrm{a}}$ & $3(10.0 \%)^{a}$ & $0^{\mathrm{a}}$ & $0^{\mathrm{a}}$ & 0.009 \\
\hline Intolerable discomfort, n (\%) & $9(30.0 \%)^{a}$ & $0^{\mathrm{b}}$ & $0^{\mathrm{b}}$ & $0^{\mathrm{b}}$ & 0.000 \\
\hline
\end{tabular}

Notes: $P<0.05$ is considered as statistically significant. ${ }^{a-c}$ The results of two comparisons; no significant statistical difference between two groups with same letter, but significant statistical differences between two groups with different letters.

Abbreviations: BMI, body mass index; C, sodium chloride; RI, remifentanil (0.I $\mu \mathrm{g} / \mathrm{kg} / \mathrm{min}) ; \mathrm{R} 2$, remifentanil $(0.2 \mu \mathrm{g} / \mathrm{kg} / \mathrm{min}) ; \mathrm{R} 3, \mathrm{remifentanil}(0.3 \mu \mathrm{g} / \mathrm{kg} / \mathrm{min})$. 
in the control group experienced intolerable discomfort with extubation. A small number of patients in the control and low-dose remifentanil groups were aware but did not experience discomfort (13.3\%) or experienced tolerable discomfort (10\%) (Table 1). These results indicated that continuous postoperative infusion of remifentanil can not only reduce coughing and discomfort responses to extubation but they can also increase respiratory depression and bradycardia.

The SAS and VAS scores of the patients in each group were recorded at emergence time ( $0 \mathrm{~min})$ and at 5,10 , and 15 min after emergence. These data were analyzed using GEEs, and the results are shown in Tables 2-5, respectively. There were significant differences in the SAS scores among the groups (Wald $\chi^{2}=17.986, P=0.000$ ), and the odds ratios (ORs) of groups R1, R2, and R3 were 0.163, 0.246, and 0.887, respectively, compared with the control group, indicating that the SAS score decreased with the remifentanil dose. The

Table 2 Number (percentage) of SAS

\begin{tabular}{|c|c|c|c|c|c|}
\hline $\begin{array}{l}\text { Emergence } \\
\text { time }\end{array}$ & Score & $\begin{array}{l}\text { Group C, } \\
\text { n (\%) }\end{array}$ & $\begin{array}{l}\text { Group RI, } \\
\text { n (\%) }\end{array}$ & $\begin{array}{l}\text { Group R2, } \\
\text { n (\%) }\end{array}$ & $\begin{array}{l}\text { Group R3, } \\
\text { n (\%) }\end{array}$ \\
\hline \multirow[t]{2}{*}{$0 \mathrm{~min}$} & 3 & 19 (63.3\%) & $6(20 \%)$ & $9(30 \%)$ & $16(53.3 \%)$ \\
\hline & 4 & II (36.7\%) & 24 (80\%) & 21 (70\%) & 14 (46.7\%) \\
\hline \multirow[t]{3}{*}{$5 \mathrm{~min}$} & 3 & I (3.3\%) & 0 & 0 & 0 \\
\hline & 4 & $19(63.3 \%)$ & $9(30 \%)$ & II (37.9\%) & 24 (80\%) \\
\hline & 5 & 10 (33.3\%) & 21 (70\%) & $18(62.1 \%)$ & $6(20 \%)$ \\
\hline \multirow[t]{2}{*}{$10 \mathrm{~min}$} & 4 & I (3.3\%) & I (3.3\%) & 0 & 0 \\
\hline & 5 & $29(96.7 \%)$ & 29 (96.7\%) & $30(100 \%)$ & $30(100 \%)$ \\
\hline \multirow[t]{3}{*}{$15 \mathrm{~min}$} & 4 & I (3.3\%) & 0 & 0 & 0 \\
\hline & 5 & $29(96.7 \%)$ & 28 (96.6\%) & 30 (100\%) & 30 (100\%) \\
\hline & 6 & 0 & I (3.4\%) & 0 & 0 \\
\hline
\end{tabular}

Abbreviations: C, sodium chloride; RI, remifentanil $(0.1 \mu \mathrm{g} / \mathrm{kg} / \mathrm{min}) ; \mathrm{R} 2$, remifentanil $(0.2 \mu \mathrm{g} / \mathrm{kg} / \mathrm{min})$; R3, remifentanil $(0.3 \mu \mathrm{g} / \mathrm{kg} / \mathrm{min}) ; \mathrm{SAS}$, sedationagitation scale.

Table 3 Correlation between SAS and the dose and infusion time of remifentanil

\begin{tabular}{|c|c|c|c|c|c|c|c|}
\hline \multirow[t]{2}{*}{ Parameters } & \multirow[t]{2}{*}{ B } & \multirow[t]{2}{*}{ OR } & \multicolumn{2}{|c|}{$95 \% \mathrm{Cl}$ of $\mathrm{OR}$} & \multicolumn{3}{|c|}{ Hypothesis test } \\
\hline & & & Lower & Upper & Wald $\chi^{2}$ & $d f$ & $P$ \\
\hline 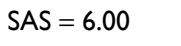 & -17.197 & 0.000 & 0.000 & 0.000 & II 4.564 & I & 0.000 \\
\hline SAS $=$ & -6.508 & 0.001 & 0.000 & 0.011 & 40.884 & I & 0.000 \\
\hline $\mathrm{SAS}=4.00$ & -.456 & 0.634 & 0.292 & 1.375 & 1.332 & I & 0.248 \\
\hline Group $=$ R3 & -.120 & 0.887 & 0.335 & 2.351 & 0.058 & I & 0.810 \\
\hline Gro & -1.404 & 0.246 & 0.090 & 0.674 & 7.436 & I & 0.006 \\
\hline Gro & -1.813 & 0.163 & 0.053 & 0.503 & 9.965 & I & 0.002 \\
\hline Gro & $0^{\mathrm{a}}$ & & & & & & \\
\hline Time $=15 \mathrm{~min}$ & -11.020 & 0.000 & 0.000 & 0.000 & 52.850 & I & 0.000 \\
\hline Time $=10 \mathrm{~min}$ & -9.904 & 0.000 & 0.000 & 0.001 & 69.864 & I & 0.000 \\
\hline Time $=5 \mathrm{~min}$ & -5.489 & 0.004 & 0.001 & 0.030 & 29.826 & I & 0.000 \\
\hline Time $=0 \mathrm{~min}$ & $0^{a}$ & & & & & & \\
\hline
\end{tabular}

Note: ${ }^{a}$ reference.

Abbreviations: $\mathrm{C}$, sodium chloride; $\mathrm{R} I$, remifentanil $(0.1 \mu \mathrm{g} / \mathrm{kg} / \mathrm{min}) ; \mathrm{R} 2$, remifentanil $(0.2 \mu \mathrm{g} / \mathrm{kg} / \mathrm{min})$; R3, remifentanil $(0.3 \mu \mathrm{g} / \mathrm{kg} / \mathrm{min})$; SAS, sedation-agitation scale; $\mathrm{Cl}$, confidence interval; $B$, regression coefficient; OR, odds ratio; $d f$, degrees of freedom.
Table 4 Number (percentage) of VAS

\begin{tabular}{|c|c|c|c|c|c|}
\hline $\begin{array}{l}\text { Emergence } \\
\text { time }\end{array}$ & Score & $\begin{array}{l}\text { Group C, } \\
\text { n (\%) }\end{array}$ & $\begin{array}{l}\text { Group RI, } \\
\text { n (\%) }\end{array}$ & $\begin{array}{l}\text { Group R2, } \\
\text { n (\%) }\end{array}$ & $\begin{array}{l}\text { Group R3, } \\
\text { n (\%) }\end{array}$ \\
\hline \multirow[t]{3}{*}{$0 \min$} & 0 & $25(83.3 \%)$ & $29(96.7 \%)$ & 29 (96.7\%) & 30 (100\%) \\
\hline & I & $3(10 \%)$ & I (3.3\%) & 0 & 0 \\
\hline & 2 & 2 (6.7\%) & 0 & I (3.3\%) & 0 \\
\hline \multirow[t]{5}{*}{$5 \mathrm{~min}$} & 0 & $3(10 \%)$ & $20(66.7 \%)$ & $13(43.3 \%)$ & $16(53.3 \%)$ \\
\hline & I & $9(30 \%)$ & $8(26.7 \%)$ & II (36.7\%) & $12(40 \%)$ \\
\hline & 2 & $13(43.3 \%)$ & $2(6.7 \%)$ & $3(10 \%)$ & $2(6.7 \%)$ \\
\hline & 3 & $5(16.7 \%)$ & 0 & $2(6.7 \%)$ & 0 \\
\hline & 5 & 0 & 0 & I (3.3\%) & 0 \\
\hline \multirow[t]{5}{*}{$10 \mathrm{~min}$} & 0 & I (3.3\%) & 7 (24.1\%) & 8 (26.7\%) & $3(10 \%)$ \\
\hline & I & I (3.3\%) & 14 (48.3\%) & 7 (23.3\%) & $13(43.3 \%)$ \\
\hline & 2 & $17(56.7 \%)$ & $8(27.6 \%)$ & $9(30 \%)$ & II (36.7\%) \\
\hline & 3 & II (36.7\%) & 0 & 4 (I3.3\%) & $3(10 \%)$ \\
\hline & 5 & 0 & 0 & $2(6.7 \%)$ & 0 \\
\hline \multirow[t]{6}{*}{$15 \mathrm{~min}$} & 0 & I (3.3\%) & I (3.3\%) & $3(10 \%)$ & I (3.3\%) \\
\hline & I & I (3.3\%) & 7 (23.3\%) & $6(20 \%)$ & $4(13.3 \%)$ \\
\hline & 2 & $9(30 \%)$ & $17(56.7 \%)$ & $12(40 \%)$ & $16(53.3 \%)$ \\
\hline & 3 & $16(53.3 \%)$ & $5(16.7 \%)$ & $5(16.7 \%)$ & $6(20 \%)$ \\
\hline & 4 & $3(10 \%)$ & 0 & $3(10 \%)$ & $3(10 \%)$ \\
\hline & 5 & 0 & 0 & I (3.3\%) & 0 \\
\hline
\end{tabular}

Abbreviations: $\mathrm{C}$, sodium chloride; $\mathrm{R}$, remifentanil $(0.1 \mu \mathrm{g} / \mathrm{kg} / \mathrm{min}) ; \mathrm{R} 2$, remifentanil $(0.2 \mu \mathrm{g} / \mathrm{kg} / \mathrm{min}) ; \mathrm{R} 3$, remifentanil $(0.3 \mu \mathrm{g} / \mathrm{kg} / \mathrm{min}) ;$ VAS, visual analog scale.

Table 5 Correlation between VAS and the dose and infusion time of remifentanil

\begin{tabular}{|c|c|c|c|c|c|c|c|}
\hline \multirow[t]{2}{*}{ Parameters } & \multirow[t]{2}{*}{ B } & \multirow[t]{2}{*}{ OR } & \multicolumn{2}{|c|}{$95 \% \mathrm{Cl}$ of OR } & \multicolumn{3}{|c|}{ Hypothesis test } \\
\hline & & & Lower & Upper & Wald $\chi^{2}$ & $d f$ & $\mathbf{P}$ \\
\hline VAS $=5.00$ & -8.913 & 0.000 & 0.000 & 0.001 & 94.411 & 1 & 0.000 \\
\hline $\mathrm{VAS}=4.00$ & -7.680 & 0.000 & 0.000 & 0.002 & 136.422 & 1 & 0.000 \\
\hline $\mathrm{VAS}=3.00$ & -5.494 & 0.004 & 0.001 & 0.013 & 87.361 & $\mathrm{I}$ & 0.000 \\
\hline $\mathrm{VAS}=2.00$ & -3.334 & 0.036 & 0.014 & 0.094 & 45.798 & $\mathrm{I}$ & 0.000 \\
\hline VAS $=1.00$ & -1.689 & 0.185 & 0.079 & 0.430 & 15.304 & 1 & 0.000 \\
\hline Group $=$ R3 & 1.765 & 5.844 & 2.635 & $|2.96|$ & 18.877 & 1 & 0.000 \\
\hline Group $=$ R2 & 1.645 & 5.183 & 1.990 & 13.503 & 11.346 & 1 & 0.001 \\
\hline Group $=$ RI & 2.332 & 10.298 & 4.479 & 23.677 & 30.135 & 1 & 0.000 \\
\hline Group $=$ C & $0^{\mathrm{a}}$ & & & & & & \\
\hline Time $=15 \mathrm{~min}$ & -6.280 & 0.002 & 0.001 & 0.006 & 122.796 & $\mathrm{I}$ & 0.000 \\
\hline Time $=10 \mathrm{~min}$ & -5.010 & 0.007 & 0.003 & 0.017 & 106.487 & 1 & 0.000 \\
\hline Time $=5 \mathrm{~min}$ & -3.489 & 0.031 & 0.014 & 0.069 & 70.966 & $\mathrm{I}$ & 0.000 \\
\hline Time $=0 \mathrm{~min}$ & $0^{\mathrm{a}}$ & & & & & & \\
\hline
\end{tabular}

Note: ${ }^{a}$ reference.

Abbreviations: $\mathrm{C}$, sodium chloride; $\mathrm{R} \mathrm{I}$, remifentanil $(0.1 \mu \mathrm{g} / \mathrm{kg} / \mathrm{min}) ; \mathrm{R} 2$, remifentanil $(0.2 \mu \mathrm{g} / \mathrm{kg} / \mathrm{min})$; R3, remifentanil $(0.3 \mu \mathrm{g} / \mathrm{kg} / \mathrm{min}) ; \mathrm{B}$, regression coefficient; OR, odds ratio; $\mathrm{Cl}$, confidence interval; VAS, visual analog scale; $d f$, degrees of freedom.

SAS scores at different times were also statistically different (Wald $\chi^{2}=74.983, P=0.000$ ), and the ORs at 5, 10, and 15 min were $0.004,0.000$, and 0.000 , respectively, compared with at $0 \mathrm{~min}$, indicating that the SAS scores increased with time after emergence. Furthermore, the VAS score analysis showed that the VAS score was associated with the remifentanil dose (Wald $\chi^{2}=32.668, P=0.000$ ) and time (Wald $\chi^{2}=$ $142.554, P=0.000$ ). The VAS score was highest in group R1 $(\mathrm{OR}=10.298,5.183$, and 5.844 in groups $\mathrm{R} 1, \mathrm{R} 2$, and $\mathrm{R} 3$, respectively) and it increased with time (OR $=0.031,0.007$, and 0.002 at 5,10 , and $15 \mathrm{~min}$, respectively). 
The cardiovascular vital signs (systolic and diastolic BP, $\mathrm{HR}, \mathrm{R}$, and $\mathrm{SPO}_{2}$ ) of the patients in each group were monitored at baseline, emergence, extubation, and 2, 5, 10, and $15 \mathrm{~min}$ after extubation. Compared with baseline, the systolic and diastolic BP, HR, and $\mathrm{SPO}_{2}$ in the control group all clearly increased at emergence, extubation, and after extubation $(P<$ $0.05)$, but $\mathrm{R}$ was significantly reduced at emergence, extubation, and after extubation $(P<0.05)$. In the $\mathrm{R} 1$ group, the diastolic BP decreased only 5 min after extubation $(P<0.05)$ and HR dramatically increased at extubation $(P<0.05)$. Systolic and diastolic BP decreased at emergence in the $\mathrm{R} 2$ and $\mathrm{R} 3$ groups $(P<0.05)$. HR increased $5 \mathrm{~min}$ after extubation in the $\mathrm{R} 2$ group $(P<0.05)$, and it decreased at emergence but increased at 5 , 10 , and 15 min after extubation in the $\mathrm{R} 3$ group $(P<0.05)$. The $\mathrm{R}$ and $\mathrm{SPO}_{2}$ decreased and increased, respectively, in the $\mathrm{R} 1, \mathrm{R} 2$, and R3 groups $(P<0.05)$. Compared with the control group, the systolic and diastolic BP in the remifentanil groups was significantly lower at emergence, extubation, and 2 and 5 min after extubation $(P<0.05)$. The HR of the remifentanil groups greatly decreased at emergence, extubation, and 2 min after extubation $(P<0.05)$. The $\mathrm{SPO}_{2}$ of the remifentanil groups showed no significant change (Table 6). These results suggest that postoperative remifentanil infusions can decrease the rise in systolic and diastolic BP, HR, and R at emergence and extubation, and they showed that the effect of a high dose of remifentanil on these variables was longer and better.

\section{Discussion}

Many studies have been carried out to explore the methods that can effectively alleviate stress responses, agitation, and discomfort due to tracheal extubation during the emergence time from general anesthesia. Vasoactive drugs, such as esmolol and ebrantil, can be used to inhibit cardiovascular responses to tracheal extubation. However, they can only improve tachycardia and hyperpiesia, and fail to inhibit the intense stimulation of the trachea by the tracheal catheter and to effectively stop the agitation and discomfort during the peri-extubation period. ${ }^{12}$ Long-acting opioid analgesics, such as fentanyl, sufentanil, and dezocine, have been used during the peri-extubation period to inhibit stress responses and discomfort, and they have been shown to have some effect. However, the controllability of long-acting opioid analgesics is poor due to longer elimination half-life and prolonged context-sensitive half-life. The use of fentanyl can not only reduce stress responses but it can also induce respiratory depression and delay recovery. ${ }^{13}$

Remifentanil is a new kind of ultra-short-acting opioid analgesic. It has many advantages such as rapid onset, shorter elimination half-life, no accumulation after long-term application, no effect caused by impaired hepatorenal function, and no prolonged context-sensitive half-life. ${ }^{14,15}$ Therefore, remifentanil may be the most easily controllable opioid analgesic. In our study, continuous injection of remifentanil after surgery decreased the number of patients with coughs and increased the patients' comfort during emergence from general anesthesia and extubation, though it also prolonged the emergence and extubation times. Furthermore, the patients treated with remifentanil had no significant adverse effects such as nausea, emesis, dizziness, headache, or uroschesis. The occurrence rates of cough and discomfort were effectively reduced, and there was no obvious occurrence of respiratory depression or bradycardia among the patients treated with remifentanil at 0.2 $\mu \mathrm{g} / \mathrm{kg} / \mathrm{min}$ after surgery. The fact that continuous injection of remifentanil after surgery can inhibit airway reflex and attenuate the stimulus of tracheal tube may account for the result. ${ }^{7,16}$

Previous research has suggested that remifentanil does not cause a decrease in the bispectral index value, ${ }^{17}$ which may be inversely correlated with the level of analgesia. ${ }^{18}$ The SAS and VAS results in this study showed that the sedative and analgesic effects were enhanced by increased doses of remifentanil, indicating that continuous postoperative infusion of remifentanil can effectively relieve postoperative pain. ${ }^{19}$ In addition, the analysis of hemodynamic vital signs showed that continuous postoperative infusion of remifentanil inhibited the elevation of systolic and diastolic BP during the peri-extubation period and that using a high dose of remifentanil $(0.3 \mu \mathrm{g} / \mathrm{kg} / \mathrm{min})$ delayed the rise in HR. This demonstrates that the postoperative use of a low dose of remifentanil can ameliorate any changes in BP and HR during the peri-extubation period, and it has beneficial effects on hemodynamic stability. ${ }^{20}$ However, the sedative and analgesic effects and hemodynamic stability were not only enhanced with the dose of remifentanil, but they also reduced with time, which suggests that the comfort of patients during the peri-extubation period was associated with the remifentanil dose ${ }^{21}$ and its short time of offset. ${ }^{22}$ Moreover, the slight changes in BP and HR caused by remifentanil can return to their original levels within 5-10 min without treatment. ${ }^{23}$

\section{Conclusion}

In our study, we showed that continuous infusion of remifentanil during peri-extubation period can effectively suppress stress and coughing responses and improve patients' comfort during the emergence phase. Furthermore, use of remifentanil at $0.2 \mu \mathrm{g} / \mathrm{kg} / \mathrm{min}$ reduced the rate of side effects compared to that at $0.3 \mu \mathrm{g} / \mathrm{kg} / \mathrm{min}$, and it may be appropriate for inhibiting stress responses to tracheal extubation under general anesthesia. Therefore, continuous postoperative infusion of remifentanil at a dose of $0.2 \mu \mathrm{g} / \mathrm{kg} / \mathrm{min}$ may be safe and comfort for tracheal extubation. 
Table 6 Comparison of SBP, DBP, HR, R, and SPO2 before surgery, emergence, extubation, and at 2, 5, I0, and I5 min after extubation

\begin{tabular}{|c|c|c|c|c|c|c|}
\hline Parameters & & SBP $(\mathrm{mmHg})$ & DBP (mmHg) & HR (beats/min) & R (beats/min) & $\mathrm{SPO}_{2}$ \\
\hline \multirow[t]{7}{*}{ Group C } & $\begin{array}{l}\text { Before surgery } \\
\text { (baseline) }\end{array}$ & $120.33 \pm 12.72$ & $70.53 \pm 9.84$ & $77.73 \pm 8.7$ & $17.57 \pm 0.97$ & $95.6 \pm 1.45$ \\
\hline & Emergence & $142.87 \pm 16.35^{* *}$ & $85.3 \pm 11.92 * *$ & $93.6 \pm 10.91 * *$ & $12.57 \pm 0.82^{* *}$ & $100 \pm 0 * *$ \\
\hline & Extubation & $146.9 \pm 16.05^{* *}$ & $86.7 \pm 11.05^{* *}$ & $97.97 \pm 12^{* *}$ & $13.17 \pm 0.7^{* *}$ & $100 \pm 0 * *$ \\
\hline & $\begin{array}{l}2 \text { min after } \\
\text { extubation }\end{array}$ & $142.33 \pm 13.63 * *$ & $82.8 \pm 11.12 * *$ & $94.2 \pm 11.13^{* *}$ & $|4.67 \pm 0.7| * *$ & $100 \pm 0 * *$ \\
\hline & $\begin{array}{l}5 \text { min after } \\
\text { extubation }\end{array}$ & $135.4 \pm 13.02 * *$ & $80.3 \pm 10.22^{* *}$ & $91.2 \pm 9.91 * *$ & $15.73 \pm 0.58 * *$ & $100 \pm 0 * *$ \\
\hline & $\begin{array}{l}10 \text { min after } \\
\text { extubation }\end{array}$ & $130.47 \pm 1 \mid .99 * *$ & $75.8 \pm 9.7 I^{* *}$ & $86.67 \pm 9.77^{* *}$ & $16.73 \pm 0.74^{* *}$ & $100 \pm 0 * *$ \\
\hline & $\begin{array}{l}15 \text { min after } \\
\text { extubation }\end{array}$ & $129.1 \pm 13.18^{* *}$ & $74.5 \pm 10.58 * *$ & $85.77 \pm 9.88 * *$ & $17.13 \pm 0.82^{*}$ & $100 \pm 0 * *$ \\
\hline \multirow[t]{7}{*}{ Group RI } & $\begin{array}{l}\text { Before surgery } \\
\text { (baseline) }\end{array}$ & $126.93 \pm 13.97$ & $77.77 \pm 10.36^{\dagger \dagger}$ & $77.03 \pm 11.79$ & $17.77 \pm 0.94$ & $94.87 \pm 2.24$ \\
\hline & Emergence & $121.8 \pm 16.27^{\dagger \dagger}$ & $72.57 \pm 11.12^{*+\dagger}$ & $78.63 \pm 14.12^{\dagger \dagger}$ & $11.67 \pm 1.06 * *+\dagger$ & $100 \pm 0 * *$ \\
\hline & Extubation & $127.43 \pm 16.5^{t+}$ & $76.17 \pm 11.36^{\dagger t}$ & $84.73 \pm 13.71 * *+\dagger$ & $12.9 \pm 0.88 * *$ & $100 \pm 0 * *$ \\
\hline & $\begin{array}{l}2 \text { min after } \\
\text { extubation }\end{array}$ & $129.43 \pm 16.04^{t \dagger}$ & $76.83 \pm 11.55^{\dagger}$ & $83 \pm\left. 13.1\right|^{* t+}$ & $14.27 \pm 0.74 * * \dagger$ & $100 \pm 0 * *$ \\
\hline & $\begin{array}{l}5 \text { min after } \\
\text { extubation }\end{array}$ & $127.77 \pm 13.78^{\dagger}$ & $73.67 \pm 11.33^{* * \dagger}$ & $82.7 \pm 10.61^{*+\dagger}$ & $15.6 \pm 0.77^{* *}$ & $100 \pm 0 * *$ \\
\hline & $\begin{array}{l}10 \text { min after } \\
\text { extubation }\end{array}$ & $127.37 \pm 17.98$ & $76 \pm 13.67$ & $85.27 \pm 11.28^{* *}$ & $16.63 \pm 0.72 * *$ & $99.97 \pm 0.18^{* *}$ \\
\hline & $\begin{array}{l}15 \text { min after } \\
\text { extubation }\end{array}$ & $129.77 \pm 18.57$ & $75.1 \pm 13.78$ & $84.73 \pm 10.83^{* *}$ & $17.37 \pm 0.56 * *$ & $100 \pm 0 * *$ \\
\hline \multirow[t]{7}{*}{ Group R2 } & $\begin{array}{l}\text { Before surgery } \\
\text { (baseline) }\end{array}$ & $126.27 \pm 14.48$ & $77.93 \pm 12.46^{\dagger}$ & $79.13 \pm 11.2$ & $17.37 \pm 0.96$ & $95.33 \pm 1.83$ \\
\hline & Emergence & $118.1 \pm|4.2|^{* *+\dagger}$ & $69.43 \pm 10.62^{* *++}$ & $75.77 \pm 13.78^{+t}$ & $12.33 \pm 1.35 * *$ & $100 \pm 0 * *$ \\
\hline & Extubation & $124.77 \pm 17.18^{\dagger \dagger}$ & $73.97 \pm 11.87^{\dagger \dagger}$ & $81 \pm 15.3^{+t}$ & $13.1 \pm 1.16^{* *}$ & $99.9 \pm 0.4^{* *}$ \\
\hline & $\begin{array}{l}2 \text { min after } \\
\text { extubation }\end{array}$ & $123.8 \pm 15.7^{\dagger \dagger}$ & $74.2 \pm 12.1^{\dagger \dagger}$ & $82.47 \pm 15.44^{\dagger \dagger}$ & $|4.4| \pm 0.95^{* *}$ & $99.87 \pm 0.57^{* *}$ \\
\hline & $\begin{array}{l}5 \text { min after } \\
\text { extubation }\end{array}$ & $126.2 \pm 18.14^{\dagger}$ & $74.3 \pm 12.83^{\dagger}$ & $85.4 \pm 14.43^{* *}$ & $15.37 \pm 0.67^{* * \dagger}$ & $99.83 \pm 0.65^{* *}$ \\
\hline & $\begin{array}{l}10 \text { min after } \\
\text { extubation }\end{array}$ & $127.83 \pm 17.63$ & $79.37 \pm 12.55$ & $85.87 \pm 14.62^{* *}$ & $16.5 \pm 0.82 * *$ & $99.8 \pm 0.8 I^{* *}$ \\
\hline & $\begin{array}{l}15 \text { min after } \\
\text { extubation }\end{array}$ & $130.77 \pm 16.86$ & $78.83 \pm 12.45$ & $85.47 \pm 14.99 *$ & $17.13 \pm 0.73$ & $99.83 \pm 0.65^{* *}$ \\
\hline \multirow[t]{7}{*}{ Group R3 } & $\begin{array}{l}\text { Before surgery } \\
\text { (baseline) }\end{array}$ & $121.4 \pm 12.84$ & $71.8 \pm 11.93$ & $77.6 \pm 10.29$ & $17.9 \pm 0.55$ & $95.9 \pm 1.45$ \\
\hline & Emergence & $114.03 \pm 11.77^{*+\dagger}$ & $65.8 \pm 8.46 *+1$ & $71.73 \pm 13.98^{*+\dagger}$ & $11.53 \pm 1.25^{* *+t}$ & $99.97 \pm 0.18^{* *}$ \\
\hline & Extubation & $118.5 \pm 13.02^{t \dagger}$ & $70.8 \pm 8.96^{t \dagger}$ & $79.23 \pm 14.14^{\dagger \dagger}$ & $12.63 \pm I^{* * t}$ & $100 \pm 0 * *$ \\
\hline & $\begin{array}{l}2 \text { min after } \\
\text { extubation }\end{array}$ & $121.37 \pm 11.6 \mathrm{I}^{\mathrm{tt}}$ & $70.33 \pm 10.6^{t+}$ & $78.87 \pm\left. 13.9\right|^{\dagger \dagger}$ & $14 \pm 0.91^{* *+\dagger}$ & $100 \pm 0 * *$ \\
\hline & $\begin{array}{l}5 \text { min after } \\
\text { extubation }\end{array}$ & $120.3 \pm 10.68^{t+}$ & $73 \pm 9.6 \mathrm{I}^{t \dagger}$ & $82.23 \pm 13.58^{*+t}$ & $15.03 \pm 0.8 \mathrm{I}^{* *+\dagger}$ & $99.9 \pm 0.4^{* *}$ \\
\hline & $\begin{array}{l}10 \text { min after } \\
\text { extubation }\end{array}$ & $|20.23 \pm 8.9|^{t+}$ & $73.1 \pm 8.03$ & $82.7 \pm 13.47^{*}$ & $16.37 \pm 0.6 \mathrm{I}^{* * \dagger}$ & $99.97 \pm 0.18^{* *}$ \\
\hline & $\begin{array}{l}15 \text { min after } \\
\text { extubation }\end{array}$ & $121.47 \pm 8.54^{\dagger}$ & $74.13 \pm 8.65$ & $82.07 \pm|2.7| *$ & $17.33 \pm 1.06^{* *}$ & $99.97 \pm 0.18^{* *}$ \\
\hline
\end{tabular}

Notes: $* P<0.05,{ }^{*} * P<0.01$ vs before surgery within-group, ${ }^{\dagger} \mathrm{P}<0.05,{ }^{\dagger} \mathrm{P}<0.0 \mathrm{I}$ vs group $\mathrm{C}$.

Abbreviations: SBP, systolic blood pressure; DBP, diastolic blood pressure; HR, heart rate; R, respiratory rate; $\mathrm{SPO}_{2}$, saturation of pulse oximetry; C, sodium chloride; RI, remifentanil ( $0.1 \mu \mathrm{g} / \mathrm{kg} / \mathrm{min})$; R2, remifentanil $(0.2 \mu \mathrm{g} / \mathrm{kg} / \mathrm{min}) ; \mathrm{R} 3$, remifentanil $(0.3 \mu \mathrm{g} / \mathrm{kg} / \mathrm{min})$.

\section{Author contributions}

JS substantially contributed to the conception and design of this study; GZ, XY, and YL substantially contributed to the acquisition of data, or analysis and interpretation of data; GZ and XY wrote the manuscript; JS revised it critically for important intellectual content and agreed to be accountable for all aspects of the work in ensuring that questions related to the accuracy or integrity of any part of the work are appropriately investigated and resolved. All authors contributed toward data analysis, drafting 
and revising the paper and agree to be accountable for all aspects of the work.

All authors have given the final approval of the version to be published.

\section{Disclosure}

The authors report no conflicts of interest in this work.

\section{References}

1. Lowrie A, Johnston PL, Fell D, Robinson SL. Cardiovascular and plasma catecholamine responses at tracheal extubation. Br J Anaesth. 1992;68(3):261-263.

2. Gacouin A, Camus C, Le Tulzo Y, et al. Assessment of peri-extubation pain by visual analogue scale in the adult intensive care unit: a prospective observational study. Intensive Care Med. 2004;30(7):1340-1347.

3. Glass PS, Gan TJ, Howell S. A review of the pharmacokinetics and pharmacodynamics of remifentanil. Anesth Analg. 1999;89(4 Suppl): S7-S14.

4. Kato M, Satoh D, Okada Y, Sugiyama K, Toda N, Kurosawa S. [Pharmacodynamics and pharmacokinetics of remifentanil: overview and comparison with other opioids]. Masui. 2007;56(11):1281-1286. Japanese [with English abstract].

5. Cavaliere F, Antonelli M, Arcangeli A, et al. A low-dose remifentanil infusion is well tolerated for sedation in mechanically ventilated, critically-ill patients. Can J Anaesth. 2002;49(10):1088-1094.

6. Marana E, Colicci S, Meo F, Marana R, Proietti R. Neuroendocrine stress response in gynecological laparoscopy: TIVA with propofol versus sevoflurane anesthesia. J Clin Anesth. 2010;22(4):250-255.

7. Aouad MT, Al-Alami AA, Nasr VG, Souki FG, Zbeidy RA, SiddikSayyid SM. The effect of low-dose remifentanil on responses to the endotracheal tube during emergence from general anesthesia. Anesth Analg 2009;108(4):1157-1160.

8. Davis PJ, Finkel JC, Orr RJ, et al. A randomized, double-blinded study of remifentanil versus fentanyl for tonsillectomy and adenoidectomy surgery in pediatric ambulatory surgical patients. Anesth Analg. 2000; 90(4):863-871.

9. Schug SA, Joshi GP, Camu F, Pan S, Cheung R. Cardiovascular safety of the cyclooxygenase-2 selective inhibitors parecoxib and valdecoxib in the postoperative setting: an analysis of integrated data. Anesth Analg. 2009;108(1):299-307.
10. Marret E, Kurdi O, Zufferey P, Bonnet F. Effects of nonsteroidal antiinflammatory drugs on patient-controlled analgesia morphine side effects: meta-analysis of randomized controlled trials. Anesthesiology. 2005;102(6):1249-1260.

11. Riker RR, Picard JT, Fraser GL. Prospective evaluation of the SedationAgitation Scale for adult critically ill patients. Crit Care Med. 1999; 27(7):1325-1329.

12. Kovac AL, Masiongale A. Comparison of nicardipine versus esmolol in attenuating the hemodynamic responses to anesthesia emergence and extubation. J Cardiothorac Vasc Anesth. 2007;21(1):45-50.

13. Safavi M, Honarmand A. Attenuation of cardiovascular responses to laryngoscopy and tracheal intubation - intravenous sufentanil vs pethidine. Middle East J Anaesthesiol. 2008;19(6):1349-1359.

14. Beers R, Camporesi E. Remifentanil update: clinical science and utility. CNS Drugs. 2004;18(15):1085-1104.

15. Schmidt GN, Bischoff P, Standl T, Lankenau G, Hilbert M, Schulte Am Esch J. Comparative evaluation of Narcotrend, Bispectral Index, and classical electroencephalographic variables during induction, maintenance, and emergence of a propofol/remifentanil anesthesia. Anesth Analg. 2004;98(5):1346-1353, table of contents.

16. Ali S. Reduced incidence of laryngospasm with remifentanil-midazolam anaesthesia compared to halothane-fentanyl. J Pak Med Assoc. 2008;58(3):111-114.

17. Guignard B, Menigaux C, Dupont X, Fletcher D, Chauvin M. The effect of remifentanil on the bispectral index change and hemodynamic responses after orotracheal intubation. Anesth Analg. 2000;90(1):161-167.

18. Iselin-Chaves IA, Flaishon R, Sebel PS, et al. The effect of the interaction of propofol and alfentanil on recall, loss of consciousness, and the Bispectral Index. Anesth Analg. 1998;87(4):949-955.

19. Calderon E, Pernia A, De Antonio P, Calderon-Pla E, Torres LM. A comparison of two constant-dose continuous infusions of remifentanil for severe postoperative pain. Anesth Analg. 2001;92(3):715-719.

20. Kelly AM, Dwamena B, Cronin P, Bernstein SJ, Carlos RC. Meta-analysis: effectiveness of drugs for preventing contrast-induced nephropathy. Ann Intern Med. 2008;148(4):284-294.

21. Machata AM, Illievich UM, Gustorff B, Gonano C, Fassler K, Spiss CK. Remifentanil for tracheal tube tolerance: a case control study. Anaesthesia. 2007;62(8):796-801.

22. Barash PG, Cullen BF, Stoelting RK, editors. Clinical Anesthesia. 5th ed. Philadelphia: Lippincott, Williams and Wilkins; 2006.

23. Casati A, Fanelli G, Albertin A, et al. Small doses of remifentanil or sufentanil for blunting cardiovascular changes induced by tracheal intubation: a double-blind comparison. Eur J Anaesthesiol. 2001;18(2):108-112.
Journal of Pain Research

\section{Publish your work in this journal}

The Journal of Pain Research is an international, peer reviewed, open access, online journal that welcomes laboratory and clinical findings in the fields of pain research and the prevention and management of pain. Original research, reviews, symposium reports, hypothesis formation and commentaries are all considered for publication.

\section{Dovepress}

The manuscript management system is completely online and includes a very quick and fair peer-review system, which is all easy to use. Visit http://www.dovepress.com/testimonials.php to read real quotes from published authors. 